\title{
The Influence of Geography Learning Based on Multicultural to Social Sensitivity of Students
}

\author{
Amin \\ Faculty of Teaching and Education \\ Islamic University "45" Bekasi, \\ Indonesia aminunisma@gmail.com
}

\begin{abstract}
This research is motivated by the fact that the students and some Indonesian people, in general, are a multicultural society which is characterized by various religions, tribes, and races that each having their own culture with values, rules, beliefs and knowledge, own language, community structure own, and political system itself. These differences often lead to conflicts between one another. Therefore, it is necessary to study multiculturalism based model which is expected to cause social sensitivity which is characterized by the ability to feel and observe the reactions or changes of others which is shows both verbally and nonverbally, so that people who have social sensitivity will certainly be a confident person to invited to hang out, many friends will like him and feel comfortable with him. The purpose of this study is to see: (1) how is the social sensitivity of students who follow conventional geography learning? (2) How is the social sensitivity of students who follow multicultural-based geography learning? And (3) are there significant differences in social sensitivity of the students on geography learning between multicultural-based learning model and conventional learning model. The research approach uses quantitative with a descriptive comparative method that is comparing the same variable for different samples. The variables in question are social sensitivity and different samples of students who follow the learning of geography based on multicultural and the students who follow the learning of geography with conventional learning model. The sampling technique was done purposively. Data collection is done by using a questionnaire that is to measure the level of social sensitivity of students after the learning takes place. While the data analysis and hypothesis testing are done by T-test free samples of two parties. The findings of this study indicate that: (1) The social cohorts of classroom students who follow conventional geographic learning can be categorized as moderate or moderate; (2) Social sensitivity of students who follow multicultural based geography learning can be categorized as high; and (3) There are significant differences in social sensitivity of the students on the learning of geography between multicultural-based learning model and conventional learning model. Therefore, it can be concluded that the learning of geography-based multicultural effect on the social sensitivity of students.
\end{abstract}

Keywords-Multicultural Based Learning; Conventional Learning; and Social Sensitivity

\section{INTRODUCTION}

The Indonesian nation is a nation that has motto Bhinneka Tunggal Ika which means Indonesia is a nation that consists of various ethnic (multicultural) but still united into one nation of Indonesia. But this motto is not yet fully grounded for every ethnicity in Indonesia. There are still many cases that show that not all ethnics are treated based on the multiculturalism views embodied in the motto of Bhinneka Tunggal Ika [1].

Each ethnic or racial tend to have an ethnocentric spirit and ideology, which states that the group is superior to other ethnic or racial groups [2]. The occurrence of not knowing each other's cultural identity can encourage the increase of prejudice against others, a form of antipathy based on mistakes that are expressed as generalizations of feeling. Prejudice is also directed to a group as a whole or to a person simply because it is a member of a particular group. Thus, prejudice has the potential to blame others for stereotypes, discrimination and social distance creation [3].

Various religions, ethnicities, races and cultural customs also occur in the school environment, students come from different walks of life with various educational backgrounds of parents, social class, and tribe and culture so that on the one hand becomes capital to build unity between differences but on the other side are concerned about potential conflict due to these differences. Therefore, it is necessary to develop education and learning based on multiculturalism. Multicultural learning is a policy in educational practice in acknowledging, accepting and affirming human differences and similarities associated with gender, race, and class [4]

Multicultural education is an attitude in regard to the uniqueness of human beings with no distinction of race, culture, sex, sex, physical condition or economic status of a person [5]. Multicultural education is an educational strategy that utilizes the diverse cultural background of learners as one of the forces to shape multicultural attitudes. This strategy is very useful, at least for schools as educational institutions can form a common understanding of the concept of culture, cultural differences, balance, and democracy in a broad sense [6]. 
Multicultural learning is basically a nation's education program so that multicultural communities can participate in realizing an ideal democratic life for their nation [7]. Multicultural based learning is built on the concept of education for freedom [7]; which aims to: (1) help students develop knowledge, attitudes, and skills to participate in democracy and freedom of society; (2) promoting freedom, competence, skills to cross ethnic and cultural boundaries to participate in several groups and cultures of others.

One of the goals of multicultural-based learning is to foster social sensitivity among students. The social sensitivity of students in terms of theoretical, referring to the conception of K.P. Scott (1991), related to empathy, pro-social, or morality. Empathy is the cognitive ability to understand the mental and emotional state of others. The indicators of empathy are (1) feeling the feelings of others and (2) understanding the feelings of others [2]. While prosocial behavior, it is a voluntary behavior to help others without wanting to get rewarded and the helper was satisfied after helping [8]. Therefore, prosocial behavior encompasses three aspects: (a) voluntary action, (b) action directed against the interests of another person or group of others, and (c) they are objectives not as a means to satisfy personal motives.

Five dimensions of multicultural education that are expected to assist teachers in implementing several programs that respond to student differences: First, the content integration dimension used by teachers to provide information with "points key "learning by reflecting on different materials; Second, the dimension of knowledge construction that helps students to understand some perspectives and formulate conclusions that are influenced by the discipline of knowledge they have; Third, the prejudice reduction dimension helps students develop positive behaviors about group differences; Fourth, the dimension of equitable pedagogy to provide equal education experience of equality and equality gains learning opportunities for different groups; and Fifth, empowering school culture and social structure, which is to empower the culture of students who are brought to school from different groups [7].

One of the strategies used in developing multicultural-based learning is Cooperative Learning. This strategy is used to indicate the development of students' ability in learning together to socialize the concept and value of local culture from their region in the learning community with friends. At the level of learning with the multicultural approach, the use of cooperative learning strategy is expected to increase the level of student participation in making recommendations of local values and build a national perspective. From this ability, students have skills in developing life skills in respect for other cultures, tolerance of diversity, accommodating, open and honest in interacting with peers of different ethnic, ethnic and cultural backgrounds, having a high empathy for other cultural differences, and able to manage conflict with non-violence (conflict nonviolent). In addition, the use of cooperative learning strategies in learning can improve the quality and effectiveness of student learning processes, a conducive learning atmosphere; build an active interaction between students and teachers, students with students in learning.
Therefore, it is interesting to do research about the difference between students' social skill between classes using cooperative learning model based on a multicultural class that uses conventional learning model.

\section{RESEARCH METHODS}

The research approach used is quantitative research with a comparative research method that is a study comparing two or more symptoms [9] which comparing social sensitivity variables for different samples. Variables are attributes or objects that have variations between one person and another person or one object with another object [10]. To facilitate and for research variables to be more operational, then presented along with the indicators of the research variables are:

TABLE 1. RESEARCH VARIABLE, VARIABLE SUB VARIABLES, AND INDICATORS

\begin{tabular}{|c|c|l|}
\hline $\mathrm{Nu}$ & $\begin{array}{c}\text { Research } \\
\text { variable }\end{array}$ & \multicolumn{1}{|c|}{ Variable Sub Variables and Indicators } \\
\hline Sensitivity & $\begin{array}{l}\text { Empathy: } \\
\text { 1. Feel the feelings of others } \\
\text { 2. Positioning yourself like everyone else }\end{array}$ \\
\hline & $\begin{array}{l}\text { Social Pro-social: } \\
\text { 1. Action was taken voluntarily } \\
\text { 2. Action intended for the benefit of } \\
\text { another person or group of others } \\
\text { 3. It is not a means to satisfy personal } \\
\text { motives. }\end{array}$ \\
\hline
\end{tabular}

The sampling technique was done purposively. The students who follow the learning of geography based on multicultural as the experimental class and the students who follow the learning of geography with conventional learning model as the control class. Data collection is done by using a questionnaire that is to measure the level of social sensitivity of students after the learning takes place. Measurements use a Likert scale consisting of item questions and the instrument has a weighted score of 1 to 5 . The questionnaire is closed; it means that respondents can only choose one of the alternative questions offered by checking $(\sqrt{ })$ on the selected answer. Respondents may choose an alternative answer to the questions offered: SL (Always), SR (Often), JR (Rarely), P (Ever), and TP (Never). While the data analysis and hypothesis testing are done by T-test free samples of two parties.

\section{RESULT AND DISCUSSION}

Based on the measurement through questionnaires after the learning took place, it can be seen that the social sensitivity of students between classes that use conventional learning with a class that uses multicultural based cooperative learning model is different. The measurement instrument consists of 15 questions or revelation with a score range of 1 to 5. Therefore, the range of social skill score ranges from 15 to 75 , so the authors classify into three, namely the score of 15-35 low social sensitivity categories; a score of 36-56 moderate social sensitivity category; and score 57-75 high social sensitivity category. 


\section{A. Control Class}

Measurement of the social sensitivity of the students in the control class is the class that does the learning by using conventional learning model did twice, which is before the learning took place and after the learning took place, can be seen in the following table:

TABLE 2. STUDENT SOCIAL SENSITIVITY CONTROL CLASS BEFORE THE LEARNING TAKES PLACE

\begin{tabular}{|c|c|c|c|}
\hline \multirow{2}{*}{$\mathrm{Nu}$} & \multirow{2}{*}{ Social Sensitivity Score } & \multicolumn{2}{|c|}{ Amount } \\
\cline { 3 - 4 } & & $\mathrm{f}$ & $\%$ \\
\hline 1 & $15-35$ & 23 & 11,43 \\
\hline 2 & $36-56$ & 8 & 65,71 \\
\hline 3 & $57-75$ & 35 & 22,86 \\
\hline \multicolumn{2}{|c}{} \\
\hline
\end{tabular}

Based on the table above, it can be seen that the social sensitivity of the students in the control class before the learning takes place, mostly medium or moderate category, that is $65.71 \%$ and the rest is low category $11.43 \%$ and high category $22.86 \%$.

TABLE 3. STUDENT SOCIAL SENSITIVITY CONTROL CLASS AFTER LEARNING TAKES PLACE

\begin{tabular}{|c|c|c|c|}
\hline \multirow{2}{*}{$\mathrm{Nu}$} & \multirow{2}{*}{ Social Sensitivity Score } & \multicolumn{2}{|c|}{ Amount } \\
\cline { 3 - 4 } & & $\mathrm{F}$ & $\%$ \\
\hline 1 & $15-35$ & 3 & 8,57 \\
\hline 2 & $36-56$ & 23 & 65,71 \\
\hline 3 & $57-75$ & 9 & 25,72 \\
\hline \multicolumn{2}{|c}{ Total } \\
\multicolumn{2}{|c}{ Source: Results of data processing, 2017} & 35 & 100 \\
\hline
\end{tabular}

Based on the table above, it is seen that the social sensitivity of the students in the control class after the learning takes place is relatively unchanged. Most of the categories are moderate or sufficient, at $65.71 \%$ and the remaining low category of $8.57 \%$ and high category of $25.72 \%$. This data shows that learning with conventional learning model relative does not affect the social sensitivity changes of its students. Although there is no change in the percentage of the social sensitivity of medium category or enough from $65,71 \%$ to $65,71 \%$, there is a slight increase of social sensitivity percentage of high category from $23 \%$ to $26 \%$ and there is a decrease of low category percentage from $11,43 \%$ to $8.57 \%$.

\section{B. Experimental Class}

Measurement the social sensitivity of the students in the experimental class is the class that does the learning by using cooperative learning model based on multiculturalism done twice; before the learning took place and after the learning took place, can be seen in the following table: TABLE 4. STUDENT SOCIAL SENSITIVITY CONTROL CLASS BEFORE THE LEARNING TAKES PLACE

\begin{tabular}{|c|c|c|c|}
\hline \multirow{2}{*}{$\mathrm{Nu}$} & \multirow{2}{*}{ Social Sensitivity Score } & \multicolumn{2}{|c|}{ Amount } \\
\cline { 3 - 4 } & & $\mathrm{F}$ & $\%$ \\
\hline 1 & $15-35$ & 3 & 8,33 \\
\hline 2 & $36-56$ & 24 & 66,67 \\
\hline 3 & $57-75$ & 9 & 25 \\
\hline \multicolumn{2}{|c}{ Total } & 36 & 100 \\
\hline
\end{tabular}

Based on the above table, it can be seen that the social sensitivity of the students in the experimental class before the learning takes place, mostly medium or moderate category, that is $66.67 \%$ and the remaining low category is $8.33 \%$ and $25 \%$ high category.

TABLE 5. STUDENT SOCIAL SENSITIVITY CONTROL CLASS AFTER LEARNING TAKES PLACE

\begin{tabular}{|c|c|c|c|}
\hline \multirow{2}{*}{$\mathrm{Nu}$} & \multirow{2}{*}{ Social Sensitivity Score } & \multicolumn{2}{|c|}{ Amount } \\
\cline { 2 - 4 } & & $\mathrm{f}$ & $\%$ \\
\hline 1 & $15-35$ & 2 & 5,56 \\
\hline 2 & $36-56$ & 11 & 30,56 \\
\hline 3 & $57-75$ & 23 & 63,88 \\
\hline \multicolumn{2}{|c}{} \\
\multicolumn{2}{|l}{ Source: Results of data processing, 2017} & 36 & 100 \\
\hline
\end{tabular}

Based on the table above, it is seen that the social sensitivity of the students in the experimental class after the learning took place has a significant change. Most categories are high, by $63 \%$ and the rest are low category $5 \%$ and moderate or moderate category $32 \%$. This data shows that learning with cooperative learning model based on multiculturalism has an effect on increasing social sensitivity of the students. This can be seen from the increasing percentage of high category social sensitivity from $25 \%$ to $63 \%$; decrease in the percentage of low category from $10 \%$ to $5 \%$ and also decrease of medium category percentage from $65 \%$ to $32 \%$.

\section{Test the hypothesis}

Hypothesis testing is done by firstly changing the hypothesis of research into a statistical hypothesis. The research hypothesis consists of $\mathrm{Ha}=$ there are significant differences of social sensitivity of the students between the classes using cooperative learning model based on multiculturalism with the class using conventional learning model, whereas $\mathrm{Ho}=$ there is no significant difference of social sensitivity of the students between the classes using cooperative learning model based on multiculturalism with classes that use conventional learning models. The statistical hypothesis is that this research is $\mathrm{Ho}=1=2$ (Ho $=$ null hypothesis i.e. there is no significant difference between 1 and 2 ) and $\mathrm{Ha}=1 \neq 2(\mathrm{Ha}=$ alternative hypothesis, i.e. there is significant difference between 1 and 2 ; where $1=$ average social sensitivity of experimental students and $2=$ average social sensitivity of control class.

Based on the data above, the author tested the hypothesis by using t-test. At the time of testing the hypothesis, the author data returned to a single data first. Based on the calculation, obtained $t$ count equal to 12,74 ; $t$ table with degrees of freedom 69 at $99 \%$ confidence level of 2.649 and $\mathrm{t}$ table with degrees of freedom 69 at $95 \%$ confidence level of 1.995 Thus because $t$ count is smaller than $\mathrm{t}$ table both at $95 \%$ and $95 \%$ confidence level, the hypothesis $\mathrm{Ha}=1 \neq 2$ thus there are significant differences in social sensitivity of students between classes that use cooperative learning model based on multiculturalism with classes using conventional learning model.

These results indicate that multicultural-based learning can improve students' sensitivity. Multicultural-based learning seeks to empower students to develop respect for people of 
different cultures, providing opportunities to work with people or groups of people of different ethnicities or races directly. Multicultural education also helps students to acknowledge the appropriateness of diverse cultural views, assist students in developing pride in their cultural heritage, and awaken students that value conflict is often the cause of conflict between community groups [11]. Multicultural education is organized in an effort to develop students' ability to view life from different cultural perspectives with their own culture, and to be positive about cultural, racial, and ethnic differences [12].

\section{CONCLUSIONS}

The learning of geography based on multiculturalism has a positive effect on the social sensitivity of the students. Social sensitivity is the ability of a person to react quickly and precisely to a particular object or social situation that surrounds it. Social sensitivity will lead people to be able to share with others, willing to help people in need, dare to apologize for making mistakes and to respect others who have different conditions.

The role of multicultural-based learning is able to increase empathy and reduce student prejudices to create intercultural (citizen) people capable of resolving nonviolent conflict, promoting social interaction process and having strong affection; provide students with the ability to build collaborative and have a high value commitment in the life of a plural society; and can contribute to the settlement and manage conflicts of racial intolerance that arise in society by increasing empathy and reducing prejudices. The condition of the diversity of society and culture positively illustrates the potential wealth of a pluralist society, but negatively people feel uncomfortable because they do not know each other's cultures.

Social sensitivity must be maintained and developed continuously in order to create a harmony of community life. Various factors that influence the quality of social sensitivity should be identified and researched. Also, need to do further research whether the social sensitivity is correlated with academic ability

\section{REFERENCES}

[1] S. Sugimoto, and A. M. Yusof, "Racial Socialization in Two Cultures", Anima Indonesian Psychological Journal, 23 (3), 2008, pp 214-221.

[2] M. Borba, Membangun Kecerdasan Moral, Jakarta: Gramedia Pustaka Utama, 2008.

[3] J. M. Bennet, and M. J. Bennet, Developing Intercultural Sensitivity, Handbook of Intercultural Training, United State: SAGE Publication, 2004.

[4] C. E., Sleeter, C. E. and Grant, Making Choices for Multicultural Education, Fife Approaches to Race, Class, and Gender, New York: Macmillan Publishing Company, 1988

[5] D. J. Skeel, Elementary Social Studies: Challenge for Tommorrow"s World, New York: Harcourt Brace College Publishers, 1995.

[6] A. Liliweri, Prasangka \& Konflik: Komunikasi Lintas Budaya Masyarakat Multikultural, Yogyakarta: LKiS, 2005.

[7] J. A., Banks, Multicultural Education: Historical Development Dimensions, and Practice, In Review of Research in Education, vol. 19, edited by L. Darling-Hammond, Washington, D.C.: American Educational Research Association, 1993.

[8] R. A. Baron and D. Byrne, Psikologi Sosial, Jakarta: Erlangga, 2005

[9] U. Silalahi, Metode Penelitian Sosial, Bandung: Refika Aditama, 2012.

[10] Hatch and Farhady, Research design and statictic for applied linguistics, Rowly, MA: Newburry, 1981

[11] T. V. Savage and S. G. Armstrong, Effective Teaching and Elementary Social Studies, Upper Saddle River, N.J : Merrill/Prentice Hall, 2008.

[12] P. J. Farris, and S. M. Cooper, Elementary Social Studies: a whole language Approach, Iowa: Brown\&benchmark Publisher, 1994 